\title{
Pedunculated early colorectal cancer with nodal metastasis: a case report
}

\author{
Hiroka Kondo ${ }^{1 *}$ (D), Shimpei Ogawa ${ }^{1}$, Takeshi Ohki ${ }^{1}$, Yoshiko Bamba', Yuka Kaneko', Kurodo Koshino', \\ Ryosuke Nakagawa', Kimitaka Tani', Fumi Maeda', Hisako Aihara', Fumiaki Tokito', Shuji Fujikawa', \\ Tomoko Yamamoto ${ }^{2}$, Yoji Nagashima ${ }^{2}$, Yuji Inoue ${ }^{1}$, Michio Itabashi $^{1}$ and Shigeki Yamaguchi ${ }^{1}$
}

\begin{abstract}
Background: Pedunculated polyps are more likely to be amenable to complete resection than non-pedunculated early colorectal cancers and rarely require additional surgery. We encountered a patient with a pedunculated early colorectal cancer that consisted of poorly differentiated adenocarcinoma with lymphatic invasion. We performed an additional bowel resection and found nodal metastasis.

Case presentation: A 43-year-old woman underwent colonoscopy after a positive fecal occult blood test. The colonoscopist found a 20-mm pedunculated polyp in the descending colon and performed endoscopic resection. Histopathologic examination revealed non-solid type poorly differentiated adenocarcinoma. The lesion invaded the submucosa (3500 $\mathrm{mm}$ from the muscularis mucosa) and demonstrated lymphatic invasion. In spite of the early stage of this cancer, the patient was considered at high risk for nodal metastasis. She was referred to our institution, where she underwent bowel resection. Although there was no residual cancer after her endoscopic resection, a metastatic lesion was found in one regional lymph node. The patient is undergoing postoperative adjuvant chemotherapy, and there has been no evidence of recurrence 3 months after the second surgery.

Conclusions: Additional bowel resection is indicated for patients with pedunculated polyps and multiple risk factors for nodal metastasis, such as poorly differentiated adenocarcinoma and lymphatic invasion. We encountered just such a patient who did have a nodal metastasis; herein, we report her case history with a review of the literature.
\end{abstract}

Keywords: Early colorectal cancer, Poorly differentiated adenocarcinoma, Pedunculated polyp

\section{Background}

Endoscopic treatment is useful for early colorectal cancer, especially for pedunculated polyps, which have a higher rate of complete resection than nonpedunculated polyps and rarely require additional bowel resection. It is uncommon for poorly differentiated adenocarcinoma to be detected at an early stage. As Dukes et al and Chung et al. report, in their studies of

* Correspondence: kondo.hiroka@twmu.ac.jp

'Department of Surgery, Institute of Gastroenterology, Tokyo Women's Medical University, 8-1, Kawada-cho, Shinjuku-ku, Tokyo, Japan

Full list of author information is available at the end of the article colorectal cancer by histological type, poorly differentiated adenocarcinoma tends to invade deeper into the bowel wall and have a higher rate of lymph node metastasis compared with well- or moderately differentiated adenocarcinoma $[1,2]$. We report our experience with a patient who had a pedunculated early colorectal cancer consisting of poorly differentiated adenocarcinoma with nodal metastasis.

\section{Case presentation}

A 43-year-old woman had a positive fecal occult blood test and underwent a diagnostic colonoscopy at a local

C C The Author(s). 2021 Open Access This article is licensed under a Creative Commons Attribution 4.0 International License, which permits use, sharing, adaptation, distribution and reproduction in any medium or format, as long as you give appropriate credit to the original author(s) and the source, provide a link to the Creative Commons licence, and indicate if changes were made. The images or other third party material in this article are included in the article's Creative Commons licence, unless indicated otherwise in a credit line to the material. If material is not included in the article's Creative Commons licence and your intended use is not permitted by statutory regulation or exceeds the permitted use, you will need to obtain permission directly from the copyright holder. To view a copy of this licence, visit http://creativecommons.org/licenses/by/4.0/ The Creative Commons Public Domain Dedication waiver (http://creativecommons.org/publicdomain/zero/1.0/) applies to the data made available in this article, unless otherwise stated in a credit line to the data. 
hospital. The colonoscopist found a $20-\mathrm{mm}$ pedunculated polyp in the descending colon and performed endoscopic resection. Histopathologic examination revealed non-solid type poorly differentiated adenocarcinoma, invading the submucosa $(3500 \mu \mathrm{m}$ from the muscularis mucosa), with lymphatic invasion. The patient was referred to our hospital for additional bowel resection.

The patient was $163-\mathrm{cm}$ tall and weighed $86.1 \mathrm{~kg}$, giving a body mass index of $32 \mathrm{~kg} / \mathrm{m}^{2}$ (slightly obese). Her medical and family history was unremarkable, and her abdominal examination yielded no significant findings. All laboratory tests were within normal limits, including the tumor markers carcinoembryonic antigen (CEA) and carbohydrate antigen 19-9 (CA19-9).

At a local hospital, endoscopy revealed a $20-\mathrm{mm}$ pedunculated polyp in the descending colon, with a depression at the apex (Fig. 1). Computed tomography performed prior to endoscopic resection showed wall thickening in the descending colon (Fig. 2) but no enlarged lymph nodes or distant metastasis.

Based on the preoperative diagnosis of descending colon cancer (T1bN0M0, stage I), we performed a laparoscopic descending colectomy with regional lymph node dissection. The surgery was uneventful, and the patient was discharged 6 days after surgery. Histopathologic examination revealed a non-solid, poorly differentiated adenocarcinoma with surrounding adenoma. According to the Haggitt classification, this was a level 2 lesion (Fig. 3) with lymphatic invasion (Fig. 4) and budding. Because there was no residual cancer after the initial endoscopic resection, the diagnosis was earlystage cancer; however, metastasis was found in one regional lymph node. Pathologically, the cancer was classified as T1bN1aM0, stage IIIA according to the TNM classification system [3]. The patient is currently undergoing postoperative adjuvant chemotherapy using S-1 (a combination of a prodrug of 5-fluorouracil, 5-chloro-24-dihydroxypyridine [CDHP], and oxonic acid).

\section{Discussion and conclusions}

Early colorectal cancer lesions, by definition, remain confined to the mucosa or submucosa, regardless of nodal metastasis [4]. Endoscopic treatment is beneficial for patients with early colorectal cancer without nodal metastasis; detailed histopathologic examination can confirm whether the resection is complete. Early colorectal cancers that invade the submucosa are classified as $\mathrm{T} 1$, with a reported nodal metastasis rate of 9 to 14.3\% [5-9]. Pedunculated polyps correspond to the Ip Paris classification [10]. According to a report by Kida et al., $68 \%$ of 122 Ip polyps they examined were adenomas, $25.4 \%$ were carcinomas in the setting of adenoma, $3.3 \%$ were intramucosal carcinomas, and the remaining 3.3\% all showed submucosal invasion (SMI) [11]. The Ip class of polyps are considered cured if they are completely resected (no cancer cells at the surgical margin), not poorly differentiated, and without lymphovascular invasion [12]; these polyps rarely require additional surgical treatment [13].

Kitajima et al. report that patients with Ip carcinoma with SMI limited to the head of the polyp and to less than $3000 \mu \mathrm{m}$, with no lymphatic invasion, have a rate of lymphatic metastasis of $0 \%$ [14]. However, if the head of the polyp invades to more than $3000 \mu \mathrm{m}$ SMI with lymphatic invasion, there is a risk for lymph node
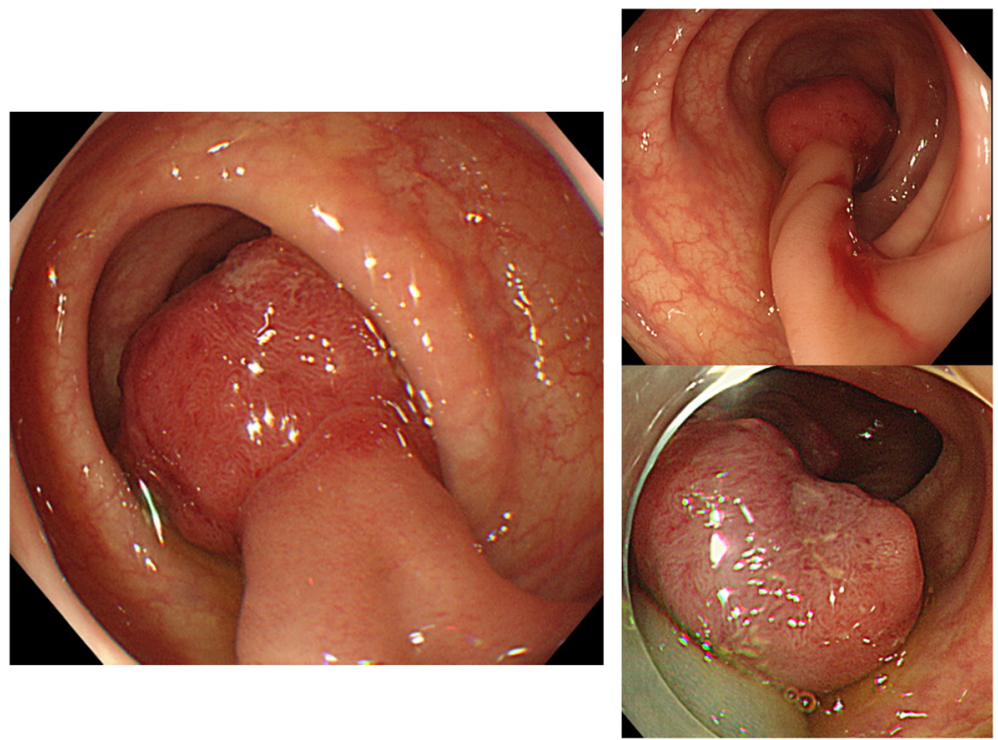

Fig. 1 Colonoscopic findings. A 20-mm pedunculated polyp is present in the descending colon, with a depression at the apex of the head 


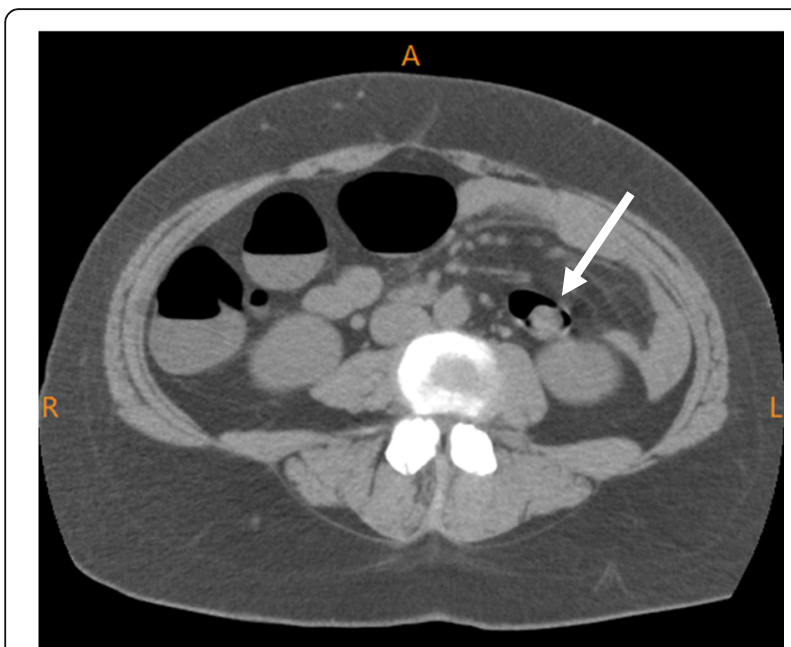

Fig. 2 Computed tomography. Imaging performed before the initial endoscopic resection shows wall thickening in the descending colon but no enlarged lymph nodes or distant metastasis

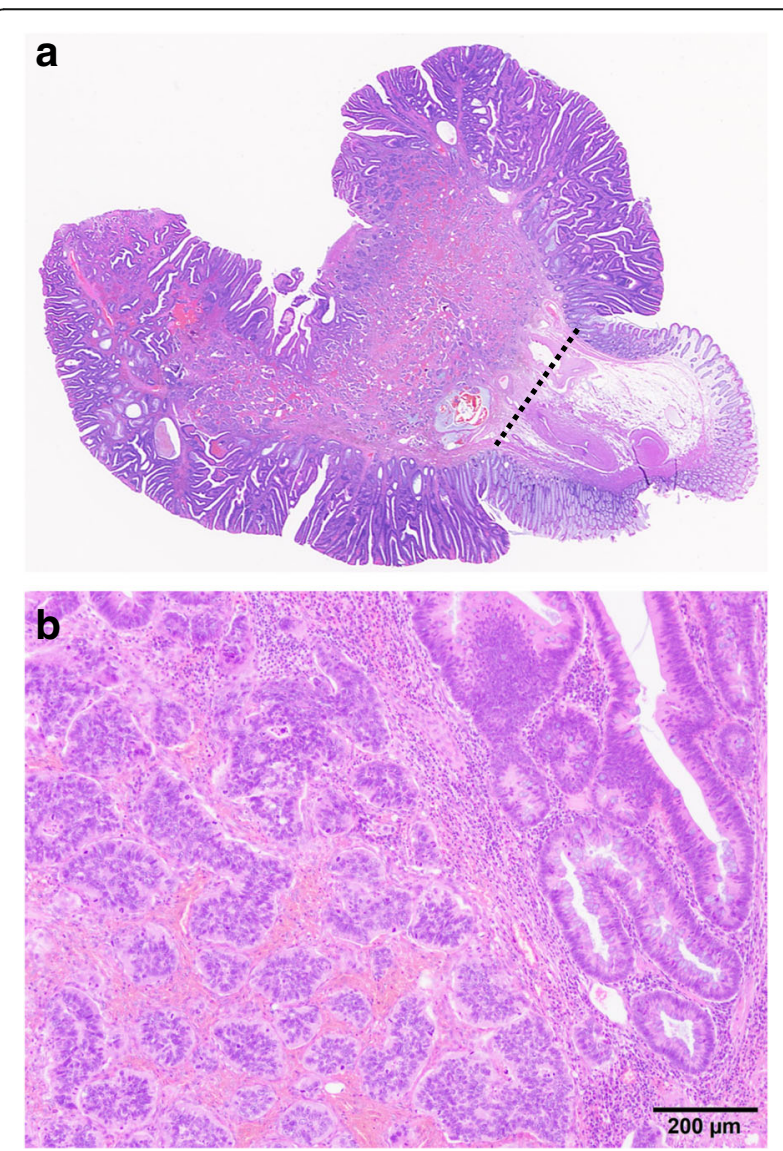

Fig. 3 Histopathologic findings. a The lesion mainly consists of nonsolid, poorly differentiated adenocarcinoma, with surrounding adenoma components. The tumor cells do not reach the Haggitt line (dotted line), indicating a level 2 Haggitt lesion. Hematoxylin-eosin staining. $\mathbf{b}$ There is a component of adenoma in the non-solid, poorly differentiated adenocarcinoma. Hematoxylin-eosin staining, $\times 10$ magnification

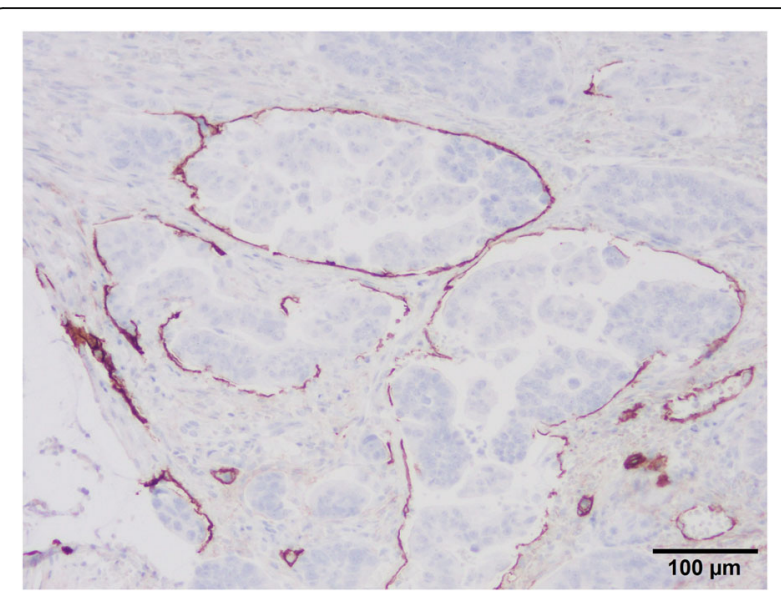

Fig. 4 Podoplanin immunostaining. Multiple tumor cells are noted in the lymphatic vessels. $\times 20$ magnification

metastasis. Haggitt et al. classified the infiltration levels of pedunculated malignant polyps into four levels: level 1: infiltrative adenocarcinoma localized to the polyp head (infiltration through the lamina muscularis mucosae); level 2: neck involvement; level 3: cancer cells in the stem; and level 4: cancer cells infiltrating the submucosal tissue at the level of the adjacent intestinal wall [15]. The Haggitt line is a theoretical border, drawn as a baseline to distinguish between head invasion and stalk invasion. If the infiltration level is less than 4 , the estimated risk for local recurrence or metastasis is low. Table 1 summarizes the results of a study of lymph node metastasis in patients with pedunculated early-stage colorectal cancer, comparing those with head invasion against those with stalk invasion [16-23].

Matsuda et al. classify invasion up to the Haggitt line as head invasion, and invasion deeper than the Haggitt line as stalk invasion. They investigated the predictive factors for lymph node metastasis in early-stage colorectal cancer of the pedunculated type and found no significant difference based on the presence of lymphatic invasion or poorly differentiated components. In that study, they noted that the depth of invasion (stalk invasion) was the only predictor of lymph node metastasis [21]. However, Tateishi et al. report that the risk for nodal metastasis is increased if any of the following are present: lymphatic invasion, poorly or moderately differentiated adenocarcinoma, or budding [7]; Sohn et al. confirm the predictive nature of budding [24]. Kimura et al. report that lymph node metastasis was present in $13.3 \%$ of their patients with head invasion; these patients had at least one of the following pathologic factors: lymphatic invasion, budding, poorly differentiated adenocarcinoma, or a mucinous carcinoma component [23]. Unfortunately, none of these prior studies examined the number of risk factors present or which combination of factors is associated with higher risk. 
Table 1 The results of a study of lymph node metastasis in patients with pedunculated early-stage colorectal cancer

\begin{tabular}{|c|c|c|c|c|c|c|}
\hline \multirow[t]{2}{*}{ Author } & \multirow{2}{*}{$\begin{array}{l}\text { Published } \\
\text { year }\end{array}$} & \multirow{2}{*}{$\begin{array}{l}\text { Number of } \\
\text { patients }\end{array}$} & \multirow{2}{*}{$\begin{array}{l}\text { Number of } \\
\text { surgical resection }\end{array}$} & \multirow{2}{*}{$\begin{array}{l}\text { Rate of lymph } \\
\text { node metastasis }\end{array}$} & \multicolumn{2}{|c|}{ Rate of lymph node metastasis } \\
\hline & & & & & Head invasion & Stalk invasion \\
\hline Shatney & 1976 & 28 & 23 & $4 \%(1 / 23)$ & $0 \%(0 / 14)$ & $1 \%(1 / 9)$ \\
\hline Nivatvongs & 1978 & 16 & 3 & $33 \%(1 / 3)$ & $0 \%(0 / 2)$ & $100 \%(1 / 1)$ \\
\hline Colacchio & 1981 & 39 & 24 & $25 \%(6 / 24)$ & $29 \%(5 / 17)$ & $14 \%(1 / 7)$ \\
\hline Cooper & 1983 & 49 & 29 & $14 \%(4 / 29)$ & $0 \%(0 / 26)$ & $17 \%(4 / 23)$ \\
\hline Pines & 1990 & 43 & 19 & $0 \%(0 / 19)$ & $0 \%(0 / 11)$ & $0 \%(0 / 8)$ \\
\hline Matsuda & 2011 & 384 & 230 & $3.5 \%(8 / 230)$ & $0 \%(0 / 101)$ & $6.2 \%(8 / 129)$ \\
\hline Asayama & 2016 & 176 & 81 & $4.9 \%(4 / 81)$ & $2.4 \%(1 / 41)$ & $7.5 \%(3 / 40)$ \\
\hline Kimura & 2016 & 76 & 76 & $11.8 \%(9 / 76)$ & $13.3 \%(4 / 30)$ & $10.9 \%(5 / 46)$ \\
\hline
\end{tabular}

Considering that the cure rate for stage III patients was $63.6 \%$, about $30 \%$ lower than that for stage I patients (91.1\%), and that the cure rate for patients with poor tumor grade was only $62 \%$ [25], determining the risk of lymph node metastasis is important even for early-stage colorectal cancer.

Our patient had a Haggitt level 2 lesion, indicating head invasion, but her cancer was poorly differentiated adenocarcinoma with a SMI depth of $3500 \mu \mathrm{m}$, positive lymphatic invasion, and budding; the risk for nodal metastasis was considered to be high. Poorly differentiated colorectal adenocarcinoma reportedly accounts for about 4 to $7 \%$ of all colorectal cancers in Japan [26, 27], but it is typically found in patients with advanced cancer. Early cancer, especially cases found in the Paris classification Ip type such as this case, is rare. It is quite rare that additional bowel resection is required for the Paris classification Ip type, and the nodal metastasis rate is about $10 \%$ in cases of SM $1000 \mu \mathrm{m}$ or more, and the remaining $90 \%$ has no nodal metastasis. On the other hand, if there are multiple factors [28], calling for additional bowel resection is required.

According to the ninth edition of the Japanese Classification of Colorectal, Appendiceal, and Anal Carcinoma, poorly differentiated adenocarcinoma of the colon is classified into two types: the solid type, in which cancer cells proliferate in a substantial manner and stroma is scarce and the non-solid type, in which fine cord-like structures predominate, glandular ducts are poorly formed, and fibrous components are abundant [29]. Due to the low prevalence of poorly differentiated adenocarcinoma of the colon, there are few studies that compare the solid type with the non-solid type. However, of the poorly differentiated adenocarcinomas, the non-solid type is significantly more likely to demonstrate nodal metastasis, liver metastasis, and peritoneal dissemination than the solid type, and it has a poor prognosis [30].

Considering that laparoscopic surgery is now commonly performed and is less invasive than laparotomy [31], surgeons should not hesitate to recommend additional bowel resection for patients with multiple factors for metastasis (such as a greater SMI distance, lymphatic invasion, and budding), rather than deciding the treatment policy based on the Haggitt classification of Ip lesions.

We report our experience with a patient who had a pedunculated early colorectal cancer consisting of poorly differentiated adenocarcinoma with nodal metastasis. In early-stage colorectal cancer of the pedunculated type, even if the invasion is limited to the head of the polyp, additional bowel resection should be aggressively considered if patients have other risk factors for lymph node metastasis.

\section{Abbreviations}

CEA: Carcinoembryonic antigen; CA19-9: Carbohydrate antigen 19-9; CDHP: 5Chloro-2-4-dihydroxypyridine; SMI: Submucosal invasion

\section{Acknowledgements}

The authors thank the experts at BioMed Proofreading for providing English copyediting services.

The authors wish to thank Tokito Clinic for sharing this instructive patient with us.

\section{Authors' contributions}

SY performed the preoperative investigation, and SY and YN provided academic advice. HK, HA, and SY performed the surgery. YN and TY performed the pathologic evaluation. HK drafted the manuscript. The authors have read and approved the final manuscript.

\section{Funding}

None of the authors have any funding to disclose.

\section{Availability of data and materials}

All data generated or analyzed during this study are presented in this article.

\section{Declarations}

Ethics approval and consent to participate

The institutional review board at the Tokyo Women's Medical University confirmed that no ethical approval is required for this case report. The patient granted consent for the publication of her report.

Consent for publication

We obtained the patient's consent for publication of this case report.

Competing interests

The authors declare that they have no competing interests. 


\section{Author details}

'Department of Surgery, Institute of Gastroenterology, Tokyo Women's Medical University, 8-1, Kawada-cho, Shinjuku-ku, Tokyo, Japan. ${ }^{2}$ Department of Surgical Pathology, Tokyo Women's Medical University, Tokyo, Japan.

\section{Received: 5 June 2021 Accepted: 27 August 2021}

Published online: 03 September 2021

\section{References}

1. Dukes CE, Bussey HJ. The spread of rectal cancer and its effect on prognosis. $\mathrm{Br}$ J Cancer. 1958;12(3):309-20. https://doi.org/10.1038/bjc.1958.37.

2. Chung CK, Zaino RJ, Stryker JA. Colorectal carcinoma: evaluation of histologic grade and factors influencing prognosis. J Surg Oncol. 1982;21(3): 143-8. https://doi.org/10.1002/jso.2930210302.

3. UICC. TNM classification of malignant tumors. 8th ed. New York: Wiley; 2017.

4. Shimoda T, Ikegami M, Fujisaki J, Matsui T, Aizawa S, Ishikawa E. Early colorectal carcinoma with special reference to its development de novo. Cancer. 1989;64(5):1138-46. https://doi.org/10.1002/1097-0142(19890901)64: 5<1138::AID-CNCR2820640529>3.0.CO;2-A.

5. Egashira Y, Yoshida T, Hirata I, Hamamoto N, Akutagawa H, Takeshita A, et al. Analysis of pathological risk factors for lymph node metastasis of submucosal invasive colon cancer. Mod Pathol. 2004;17(5):503-11. https:// doi.org/10.1038/modpathol.3800030.

6. Nascimbeni R, Burgart LJ, Nivatvongs S, Larson DR. Risk of lymph node metastasis in T1 carcinoma of the colon and rectum. Dis Colon Rectum. 2002;45(2):200-6. https://doi.org/10.1007/s10350-004-6147-7.

7. Tateishi $Y$, Nakanishi $Y$, Taniguchi H, Shimoda T, Umemura S. Pathological prognostic factors predicting lymph node metastasis in submucosal invasive (T1) colorectal carcinoma. Mod Pathol. 2010;23(8):1068-72. https:// doi.org/10.1038/modpathol.2010.88.

8. Okabe S, Shia J, Nash G, Wong WD, Guillem JG, Weiser MR, et al. Lymph node metastasis in T1 adenocarcinoma of the colon and rectum. J Gastrointest Surg. 2004;8(8):1032-9; discussion 1039-1040. https://doi.org/1 0.1016/j.gassur.2004.09.038.

9. Tominaga K, Nakanishi Y, Nimura S, Yoshimura K, Sakai Y, Shimoda T. Predictive histopathologic factors for lymph node metastasis in patients with nonpedunculated submucosal invasive colorectal carcinoma. Dis Colon Rectum. 2005;48(1):92-100. https://doi.org/10.1007/s10350-004-0751-4.

10. The Paris endoscopic classification of superficial neoplastic lesions: esophagus, stomach, and colon: November 30 to December 1, 2002. Gastrointest Endosc. 2003;58(6 Suppl):S3-43. https://doi.org/10.1016/S00165107(03)02159-X.

11. Kida M, Tanaka K, Hattori F, Kondou S, Harada W, Takagi A, et al. Clinicopathological studies on Is, Ip polyps and flat elevations in the large intestine. Nihon Shokakibyo Gakkai Zasshi. 1990:87(5):1154-9.

12. Bujanda L, Cosme A, Gil I, Arenas-Mirave J. Malignant colorectal polyps. World J Gastroenterol. 2010;16(25):3103-11. https://doi.org/10.3748/wjg.v16. i25.3103.

13. Aarons CB, Shanmugan S, Bleier Jl. Management of malignant colon polyps: current status and controversies. World J Gastroenterol. 2014;20(43):1617883. https://doi.org/10.3748/wjg.v20.i43.16178.

14. Kitajima K, Fujimori T, Fujii S, Takeda J, Ohkura Y, Kawamata H, et al. Correlations between lymph node metastasis and depth of submucosal invasion in submucosal invasive colorectal carcinoma: a Japanese collaborative study. J Gastroenterol. 2004;39(6):534-43. https://doi.org/10.1 007/s00535-004-1339-4.

15. Haggitt RC, Glotzbach RE, Soffer EE, Wruble LD. Prognostic factors in colorectal carcinomas arising in adenomas: implications for lesions removed by endoscopic polypectomy. Gastroenterology. 1985;89(2):328-36. https:// doi.org/10.1016/0016-5085(85)90333-6.

16. Shatney $\mathrm{CH}$, Lober PH, Gilbertson V, Sosin H. Management of focally malignant pedunculated adenomatous colorectal polyps. Dis Colon Rectum. 1976;19(4):334-41. https://doi.org/10.1007/BF02590930.

17. Nivatvongs S, Goldberg SM. Management of patients who have polyps containing invasive carcinoma removed via colonoscope. Dis Colon Rectum. 1978;21(1):8-11. https://doi.org/10.1007/BF02586537.

18. Colacchio TA, Forde KA, Scantlebury VP. Endoscopic polypectomy: inadequate treatment for invasive colorectal carcinoma. Ann Surg. 1981; 194(6):704-7. https://doi.org/10.1097/00000658-198112000-00008.
19. Cooper HS. Surgical pathology of endoscopically removed malignant polyps of the colon and rectum. Am J Surg Pathol. 1983;7(7):613-23. https://doi. org/10.1097/00000478-198310000-00002.

20. Pines A, Bat L, Shemesh E, Ron E, Horowitz A, Chetrit A, et al. Invasive colorectal adenomas: surgery versus colonoscopic polypectomy. J Surg Oncol. 1990;43(1):53-5. https://doi.org/10.1002/jso.2930430114.

21. Matsuda T, Fukuzawa M, Uraoka T, Nishi M, Yamaguchi Y, Kobayashi N, et al. Risk of lymph node metastasis in patients with pedunculated type early invasive colorectal cancer: a retrospective multicenter study. Cancer Sci. 2011;102(9):1693-7. https://doi.org/10.1111/j.1349-7006.2011.01997.x.

22. Asayama N, Oka S, Tanaka S, Nagata S, Furudoi A, Kuwai T, et al. Long-term outcomes after treatment for pedunculated-type $\mathrm{T} 1$ colorectal carcinoma: a multicenter retrospective cohort study. J Gastroenterol. 2016;51(7):702-10. https://doi.org/10.1007/s00535-015-1144-2.

23. Kimura YJ, Kudo SE, Miyachi H, Ichimasa K, Kouyama Y, Misawa M, et al. 'Head invasion' is not a metastasis-free condition in pedunculated T1 colorectal carcinomas based on the precise histopathological assessment. Digestion. 2016;94(3):166-75. https://doi.org/10.1159/000450942.

24. Sohn DK, Chang HJ, Park JW, Choi DH, Han KS, Hong CW, et al. Histopathological risk factors for lymph node metastasis in submucosal invasive colorectal carcinoma of pedunculated or semipedunculated type. J Clin Pathol. 2007:60(8):912-5. https://doi.org/10.1136/jcp.2006.043539.

25. van den Berg I, RRJ C $\vee d$ B, JLA $\vee$ V, JNM I, Buettner S. Actual survival after resection of primary colorectal cancer: results from a prospective multicenter study. World J Surg Oncol. 2021;19:96.

26. Ogawa M, Watanabe M, Eto K, Kosuge M, Yamagata T, Kobayashi T, et al. Poorly differentiated adenocarcinoma of the colon and rectum: clinical characteristics. Hepatogastroenterology. 2008;55(84):907-11.

27. Takeuchi K, Kuwano H, Tsuzuki Y, Ando T, Sekihara M, Hara T, et al. Clinicopathological characteristics of poorly differentiated adenocarcinoma of the colon and rectum. Hepatogastroenterology. 2004;51:1698-702.

28. Pimentel-Nunes P, Dinis-Ribeiro M, Ponchon T, Repici A, Vieth M, De Ceglie A, et al. Endoscopic submucosal dissection: European Society of Gastrointestinal Endoscopy (ESGE) Guideline. Endoscopy. 2015;47(9):829-54. https://doi.org/10.1055/s-0034-1392882.

29. JSCCR. Japanese classification of colorectal, appendiceal, and anal carcinoma. 9th ed. Ltd, Tokyo: Kanehara \& Co; 2018.

30. Sugao Y, Yao T, Kubo C, Tsuneyoshi M. Improved prognosis of solid-type poorly differentiated colorectal adenocarcinoma: a clinicopathological and immunohistochemical study. Histopathology. 1997;31(2):123-33. https://doi. org/10.1046/j.1365-2559.1997.2320843.X.

31. Endo S, Takehara Y, Tanaka J, Hidaka E, Mukai S, Omoto T, et al. Complete laparoscopic surgery for early colorectal cancer after endoscopic resection. Asian J Endosc Surg. 2013:6(4):338-41. https://doi.org/10.1111/ases.12045.

\section{Publisher's Note}

Springer Nature remains neutral with regard to jurisdictional claims in published maps and institutional affiliations.
Ready to submit your research? Choose BMC and benefit from:

- fast, convenient online submission

- thorough peer review by experienced researchers in your field

- rapid publication on acceptance

- support for research data, including large and complex data types

- gold Open Access which fosters wider collaboration and increased citations

- maximum visibility for your research: over $100 \mathrm{M}$ website views per year

At $\mathrm{BMC}$, research is always in progress.

Learn more biomedcentral.com/submissions 